\title{
In vivo Hypoglycemic Activities of Male and Female Antidesma bunius (L.) Spreng. In Alloxan-induced Diabetic Mice
}

\author{
SHERYL JOYCE B. GRIJALDO', NOEL S. QUIMING²*, MARILOU G. NICOLAS², \\ and MICHAEL RUSSELLE S. ALVAREZ ${ }^{1}$
}

${ }^{1}$ Institute of Chemistry, University of the Philippines Los Baños, Laguna, Philippines.

${ }^{2}$ Department of Physical Sciences and Mathematics, College of Arts and Sciences,

University of the Philippines Manila, Manila City, Philippines.

${ }^{*}$ Corresponding author E-mail: nsquiming@up.edu.ph

http://dx.doi.org/10.13005/ojc/350421

(Received: May 30, 2019; Accepted: July 12, 2019)

\begin{abstract}
Diabetes mellitus, a complex chronic disease that is associated with hyperglycemia (high blood sugar) affects millions of people worldwide. This study evaluated the hypoglycemic activities of male and female Antidesma bunius, commonly known as currant tree or bignay, extracts in alloxan-treated ICR mice. In addition, the effects of the treatments on blood urea nitrogen (BUN) and creatinine levels were determined. Phytochemical screening using standard protocol was performed. Plant extracts $(500 \mathrm{mg} / \mathrm{kg})$ were administered orally via gavage for 14 days and fasting blood glucose (FBG) levels were monitored prior to alloxan-induction on the day of alloxan-induction, and on the $3^{\text {rd }}, 7^{\text {th }}$ and $14^{\text {th }}$ days of treatment. Sera were collected on the $14^{\text {th }}$ day to measure the BUN and creatinine levels. Phytochemical screening was performed using standard TLC spray tests. All extracts were found to significantly lower FBG levels compared to the positive (glibenclamide $10 \mathrm{mg} / \mathrm{kg}$ ) and negative (distilled water) controls (One-way ANOVA, $\mathrm{p}$-value $<0.0001$ ). The most active extract, aqueous male $A$. bunius extract, significantly lowered FBG levels by as much as $61.26 \pm 17.89 \%$ after the $14^{\text {th }}$ day (paired t-test, $p$-value $=0.0211$ ). Both BUN and creatinine values were found to be significantly different in the treated mice compared to the controls (One-way ANOVA, p-value $=0.0005$ and 0.000479 , respectively). The BUN level of all mice was still within normal range, unlike with the creatinine level where only the female and male aqueous $A$. bunius and female ethanolic $A$. bunius extracts were within normal range. Phytochemical screening showed the presence of saponins, tannins, and polyphenols, phlobatannins, steroids and terpenoids. This study demonstrates the potential of male and female $A$. bunius leaf extracts to reduce fasting blood glucose levels. Additional work, pertaining to the identification of possible bioactive compounds and establishing the mechanisms thereof, could be performed.
\end{abstract}

Keywords: Antidesma bunius, Blood urea nitrogen, Creatinine, Hypoglycemic activity, Phytochemistry.

This is an Open Access article licensed under a Creative Commons license: Attribution 4.0 International (CC- BY). Published by Oriental Scientific Publishing Company @ 2018 


\section{INTRODUCTION}

Diabetes mellitus is a complex chronic condition that occurs when the pancreas does not produce enough insulin, or when the body cannot effectively use the insulin it produces hyperglycemia is a common symptom of diabetes and over time leads to serious damage to many of the body's systems, especially the nerves and blood vessels'. The number of people in the world with diabetes has increased dramatically in recent years. According to the International Diabetes Federation (2014), the number of diabetes cases (age 20-29) in the Philippines was 3, 256, 210 with a raw national prevalence of $6.01 \%^{2}$. Most of the end-stage renal disease is caused by type II diabetes ${ }^{3}$. Alloxan induces diabetes (type II diabetes) by selectively killing insulinproducing pancreatic $\beta$-cells, causing a diabetic nonobese animal model. Alloxan induction also causes renal changes such as nephrotoxic alterations, due to the hyperglycemia-induced elevation of plasma urea and creatinine ${ }^{4}$. Long-term complications of diabetes mellitus include elevated plasma levels of urea and creatinine, which correlates to the severity of renal disease in diabetic patients. Thus, both can be used to assess kidney function.

Several drugs such as insulin sensitizers (biguanides, metformin) and insulin secretagogues (sulfonylureas, meglitinides) are presently available to reduce hyperglycemia in Diabetes mellitus. Most of these glucose-lowering drugs, however, may have side effects such as severe hypoglycemia, lactic acidosis, idiosyncratic liver cell injury, permanent neurological deficit, digestive discomfort, and even death ${ }^{5}$. Thus, searching for a new class of compounds is essential to counter problems such as high cost and poor availability of the current medicines. More than 1,200 plants have already been described to be used in the treatment of diabetes, including Anabasis articulata (Forssk.) Moq. [Synonym: Anabasis articulata var. Ascendenx Le Houér] ${ }^{6}$, Momordica charantia L. [Synonyms: Momordica charantia f. abbreviata (Ser.) W. J. de Wilde \& Duyfjes, Momordica charantia var. abbreviata Ser., Momordica charantia var. Iongirostrata Cogn., Momordica charantia var. muricata (Willd.) Chakrav], Andrographis paniculata (Brum.f.) Nees [Synonym: Andrographis paniculata var. glandulos Trimen], and Lagerstroemia speciosa (L.) Pers. [Lagerstroemia speciosa var. intermedia (Koehne) Furtado \&
Montien] ${ }^{7,8}$. Antidesma bunius Linn. (Spreng.) [Family: Phyllanthaceae] [English name: Chinese-laurel, Herbert River-cherry, Queensland-cherry, salamander tree, wild cherry, currant tree] [Synonyms: Antidesma bunius var. bunius, Antidesma bunius var. cordifolium (C.Presl) Müll.Arg., Antidesma bunius var. floribundum (Tul.) Müll.Arg., Antidesma bunius var. pubescens Petra Hoffm., Antidesma bunius var. sylvestre (Lam.) Müll.Arg., Antidesma bunius var. thwaitesianum (Müll. Arg.) Trimen, Antidesma bunius var. wallichii Müll.Arg.] locally named as bignay is a dioecious tree, widely used in the Philippines as antidysentery, antioxidative, anticancer agents and as well as astringent and thirst quencher ${ }^{9}$. Ethnobotanical reports in the Philippines show that leaf decoction is used for blood sugar level management ${ }^{10}$. The fruits contain flavonoids, phenolics and organic acids ${ }^{11}$ while the leaves and bark contain Dammara-20, 24-dien-3 $\beta$-ol, fridelin, epitaraxerol and other triterpenoids ${ }^{12}$.

Dioecious plant species are those that have distinct male and female individual plants ${ }^{13}$. Its effect on ethnopharmacology have been documented previously, wherein traditional healers in India would have gender preferences for their herbal medicines ${ }^{14}$. The effect of dioecy on secondary metabolites have been established for several plant species, such as Mauritia flexuosa ${ }^{15}$, Tinospora cordifolia ${ }^{16}$ and Piper betle $^{17}$. For $A$. bunius, however, such analyses and its correlation to bioactivity have not been reported yet.

The study aims to evaluate the effects of the aqueous and ethanolic leaf extracts of both male and female species of Antidesma bunius Linn. (Spreng.) on blood glucose level, blood urea nitrogen, and creatinine levels of alloxanized mice over a 14-day period.

\section{MATERIALS AND METHODS}

\section{Plant material}

Fresh and adult male and female bignay leaves were collected from the vicinity of Mt. Makiling, Los Baños, Laguna (Fig. 1). Plant materials were identified, authenticated, and deposited (male A. bunius: \#073651, female $A$. bunius: \#073650) at the Botanical Herbarium of Museum on Natural History from University of the Philippines Los Baños, Laguna. 


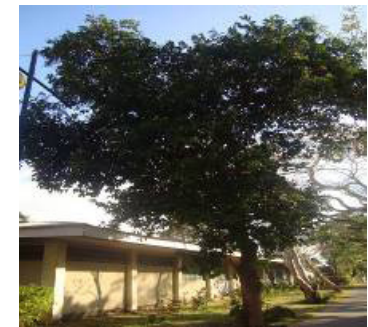

(a)

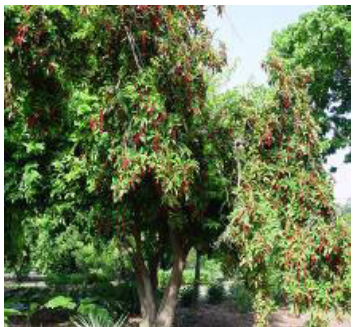

(b)
Fig. 1. Male (A) and female (B) A. bunius trees at the collection site in Laguna, Philippines

\section{Animals and Induction of Type II Diabetes}

Twenty eight (28) fifteen-week old ICR strain male and female mice (Research Institute of Tropical Medicine, Department of Health, Alabang, Muntinlupa, Metro Manila) weighing 25 to $40 \mathrm{~g}$ were purchased and acclimated for a week. The mice were caged individually and maintained on ambient laboratory condition. Chow diet, and water (Wilkins ${ }^{\circledR}$ ) were given ad libitum. The procedures involving animal subjects were approved by the Institutional Animal Care and Use Committee, National Institutes of Health, University of the Philippines Manila.

The mice were subjected for an $8 \mathrm{~h}$ fasting and the fasting blood glucose (FBG) levels were determined using a glucometer and glucose strips (One Touch Ultra ${ }^{\text {TM }}$, Johnson \& Johnson Co.). An aqueous solution of alloxan monohydrate (Belman Laboratories, Quezon City, Philippines) was injected intraperitoneally to each mice at a ratio of $200 \mathrm{mg} /$ $\mathrm{kg}$. A $5 \%$ glucose solution was given to counteract the hypoglycemic shock. Ad libitum to food and water was maintained throughout the experimental set-up. Two days after alloxan injection, mice with fasting blood glucose level $>200 \mathrm{mg} / \mathrm{dL}$ were considered diabetic and included for further study. Diabetes was allowed to develop and stabilized in the alloxantreated animals over a period of 3-5 days.

\section{Plant Extracts}

Leaves were rinsed with water, shade-dried, and powderized using an electric blender. Two hundred grams of each powdered plant sample was extracted separately with $2 \mathrm{~L}$ of distilled water and $80 \%$ ethanol for $24 \mathrm{~h}$ at room temperature with occasional stirring. All extracts were individually filtered, discarding the residue. Further, the crude extracts were lyophilized using a Chemlab SB4 freeze-drier at the Tissue Bank of the Philippine General Hospital, University of the Philippines Manila.

\section{Acute Toxicity test}

Acute oral toxicity study was performed according to the OECD (Organization for Economic Co-operation and Development) Guideline for Testing of Chemicals ${ }^{18}$. Acute toxic class test procedure with a starting dose of $2000 \mathrm{mg} / \mathrm{kg}$ body weight was adopted. Six female ICR mice were randomly selected and were fasted overnight. The extracts were administered via oral gavage at a dose of $2000 \mathrm{mg} / \mathrm{kg}$ extract in distilled water. The animals were observed continuously for $3 \mathrm{~h}$ for the gross behavioral changes and then for mortality after 2 days until 14 days.

\section{Experimental Design}

The assay was performed based on the method by Tafesse et al., (2017) with minor modifications ${ }^{19}$. The experiment was Completely Randomized Design, using a total of 28 mice consisting of 24 diabetic (type 2) mice and four normal mice were used. The mice were randomly divided into 7 groups consisting of 4 animals (Table 1). The plant extracts and controls were introduced orally via gavage into the subjects for 14 days, monitoring the FBG levels at set intervals.

\begin{tabular}{|c|c|c|}
\hline $\begin{array}{l}\text { Group } \\
\text { Number }\end{array}$ & Label & Treatment \\
\hline 1 & Normal & Normal untreated mice \\
\hline 2 & Neg. Control & $\begin{array}{l}\text { Hyperglycemic mice treated } \\
\text { with distilled water (negative } \\
\text { control) }\end{array}$ \\
\hline 3 & Pos. Control & $\begin{array}{l}\text { Hyperglycemic mice treated } \\
\text { with glibenclamide } \\
(10 \mathrm{mg} / \mathrm{kg})\end{array}$ \\
\hline 4 & $\begin{array}{c}\text { Female Aq. } \\
\text { A. Bunius }\end{array}$ & $\begin{array}{l}\text { Hyperglycemic mice treated } \\
\text { with female } A \text { bunius } \\
\text { aqueous extract }(500 \mathrm{mg} / \mathrm{kg} \text { ) }\end{array}$ \\
\hline 5 & $\begin{array}{l}\text { Male Aq. } \\
\text { A. bunius }\end{array}$ & $\begin{array}{l}\text { Hyperglycemic mice treated } \\
\text { with male } A \text {. bunius aqueous } \\
\text { extract }(500 \mathrm{mg} / \mathrm{kg})\end{array}$ \\
\hline 6 & $\begin{array}{c}\text { Female EtOH } \\
\text { A. bunius }\end{array}$ & $\begin{array}{l}\text { Hyperglycemic mice treated } \\
\text { with female } A \text {. bunius } \\
\text { ethanolic extract }(500 \mathrm{mg} / \mathrm{kg})\end{array}$ \\
\hline 7 & $\begin{array}{l}\text { Male } \mathrm{EtOH} \\
\text { A. bunius }\end{array}$ & $\begin{array}{l}\text { Hyperglycemic mice treated } \\
\text { with male } A \text {. bunius ethanolic } \\
\text { extract }(500 \mathrm{mg} / \mathrm{kg})\end{array}$ \\
\hline
\end{tabular}

\section{Biochemical Assays}

The FBG levels were monitored, and recorded prior to and on day $0,3,7,14^{\text {th }}$ after the induction of diabetes; this was done by collecting 
blood samples from the tail vein. Body weights of animals were recorded daily during the study period. FBG concentration was determined using One Touch Ultra ${ }^{\mathrm{TM}}$ glucometer and compatible blood glucose strips at regular time intervals i.e. before and after alloxan injection and $3^{\text {rd }}, 7^{\text {th }}$, and $14^{\text {th }}$ day from Day zero.

For estimating urea and creatinine, serum was isolated from the blood collected by cardiac puncture under mild anesthesia (Zoletil-50, Provisions Marketing, Philippines) from $8 \mathrm{~h}$ fasted mice on day 14 of the experimental treatment. Serum urea and creatinine were measured by United Diagnostic Laboratories, Ermita, Manila using the LiquiCHEK $^{\mathrm{TM}}$ (AGAPPE) and NewTech Creatinine reagent kits, respectively, using manufacturer's instructions. For the measurement of serum urea, $1000 \mu \mathrm{L}$ of the working reagent ( $80 \mathrm{mM}$ Tris Buffer, $\mathrm{pH}$ 7.60; $0.56 \mathrm{mM}$ ADP; $7.2 \mathrm{mM} \alpha$-ketoglutarate; $5200 \mathrm{U} / \mathrm{L}$ urease; $880 \mathrm{U} / \mathrm{L}$ GLDH; 0.05 mM NADH; $1 \mathrm{mM}$ 2-oxoglutarate) was mixed with $10 \mu \mathrm{L}$ of the diluted serum samples or $10 \mu \mathrm{L}$ of the standard (50 mg/dL) and then incubated at $37^{\circ} \mathrm{C}$. The optical density $\left(\lambda_{\max }=340 \mathrm{~nm}\right)$ was first read after $30 \mathrm{sec}$. of incubation $\left(T_{1}\right)$ and then after $90 \mathrm{sec}$ of incubation $\left(T_{2}\right)$. Serum urea was calculated using the following equation:

UREA BUN $\left(\frac{m g}{d L}\right)=\frac{T_{1, \text { sample }}-T_{2, \text { sample }}}{T_{1, \text { standard }}-T_{2, \text { standard }}} * 23.4$

Creatinine quantification was done according to the Jaffe protocol. $1 \mathrm{ml}$ (for consistency) of the working reagent (8.76 mM picric acid; 0.145 M sodium hydroxide) was incubated with either 100 $\mu \mathrm{L}$ sample (serum diluted 50 -fold with distilled water) or $100 \mu \mathrm{L}$ standard ( $2 \mathrm{mg} / \mathrm{dL}$ ). Absorbance at 492 $\mathrm{nm}$ were measured after 30 seconds $\left(A_{1}\right)$ and 90 seconds $\left(A_{2}\right)$ of incubation. Serum creatinine was calculated using the following equation:

sreatinine $\left(\frac{m g}{d L}\right)=\frac{\left(A_{1, \text { sample }}-A_{2, \text { sample }}\right)-\left(A_{1, \text { blank }}-A_{2, \text { blank }}\right)}{\left(A_{1 . \text { standard }}-A_{2 . \text { standard }}\right)-\left(A_{1 . \text { blank }}-A_{2 . \text { blank }}\right)} * 2$

\section{Statistical Analysis}

Assays were performed in triplicate. Statistics were performed using GraphPad Prism 7 software with significance level of $0.05(\alpha=0.05)$. Comparison among groups were analyzed using one-way ANOVA with Dunnett's post-hoc test. Comparison within groups (Day 0 as pretest and Day 3, 7, and 14 as post-tests) were done using paired sample t-test. Creatinine and urea values were compared among groups using one-way ANOVA with
Dunnett's post-hoc test. Weights of the mice prior to induction (Basal) and after the treatment period (Day 14) were compared using paired sample t-test.

\section{Phytochemical Screening}

Qualitative chemical tests were carried out on the aqueous extract and on the powdered specimens using standard procedures to identify the constituents as described by Edeoga $(2005)^{20}$ :

Test for Flavonoids. $2 \mathrm{ml}$ crude extract was heated in steambath until incipient dryness. It was cooled at room temperature. It was then defatted by adding 2:1 v/v hexane and distilled water. Hexane extract was discarded after. After addition of 10 $\mathrm{ml}$ of $80 \%$ ethanol, it was filtered and divided into 3 portions; one being the control. The first filtrate was tested using bate-Smith and Metcalf Test. $0.5 \mathrm{ml}$ of $12 \mathrm{M} \mathrm{HCl}$ was added and observed for color change. It is then warmed for 15 min and was observed for color change in an hour. It was compared with the control. The second filtrate was tested using Wilstatter "cyanidin" test. After the addition of 0.5 $\mathrm{ml}$ of $12 \mathrm{M} \mathrm{HCl}, 3-4$ pieces of magnesium turnings were added. Color change was observed within 10 min and was compared with the control. Positive results include change of orange to red, crimson to magenta, and green to blue.

Test for Alkaloids. $10 \mathrm{~g}$ of crude powder in syrupy consistency was added with $2.5 \mathrm{ml} 2 \mathrm{M} \mathrm{HCl}$. It was heated and stirred for 5 minutes. After cooling, $0.25 \mathrm{~g}$ of $\mathrm{NaCl}$ was added and then filtered. The residue was washed with $2 \mathrm{M} \mathrm{HCl}$. Filtrate is divided into 3 with ratio 1:1:2. The first 2 filtrates were tested with Mayer's and Dragendorff's reagents separately. The third filtrate is used for the confirmatory test and was added with $28 \% \mathrm{NH} 3$ dropwise until alkaline to litmus. Less $5 \mathrm{ml}$ chloroform was added after. The lower chloroform layer was dried in a steambath on the hood. $5 \mathrm{ml}$ of $2 \mathrm{M} \mathrm{HCl}$ was added and then was heated while stirring in 2 minutes. It was then tested with Mayer's and Dragendorff's reagents separately. The upper aqueous layer, on the other hand, was acidified with $2 \mathrm{M} \mathrm{HCl}$. After filtering, it was divided into two and tested with Mayer's and Dragendorff's reagents. White precipitation is a positive result for the Mayer's test while orange precipitation is a positive result for the Dragendorff's test. 
Test for Saponins. $2 \mathrm{~g}$ of crude extract was dissolved in $20 \mathrm{ml}$ distilled water and was boiled in a water bath. It was filtered $10 \mathrm{ml}$ of filtrate was mixed with $5 \mathrm{ml}$ distilled water and was shaken vigorously 3 drops of olive oil was added and again was shaken vigorously. Formation of emulsion is a positive indication of saponins.

Test for Tannins. $0.5 \mathrm{~g}$ of the crude powder was boiled with $20 \mathrm{ml}$ of distilled water. This was filtered and drops of $0.1 \%$ ferric chloride reagent was added to the filtrate. A blue-black or brownish green coloration was taken as evidence for the presence of tannin.

Test for Phlobatannins. An aqueous extract of each plant sample was boiled with $1 \%$ aqueous hydrochloric acid $(\mathrm{HCl})$ to observe the deposition of red precipitate.

Test for Terpenoids. $5 \mathrm{ml}$ plant extract was added with $2 \mathrm{ml}$ chloroform. The test tube was inclined and $3 \mathrm{ml}$ concentrated sulfuric acid was added slowly. A reddish brown coloration of the interface was observed as an indication of terpenoids.

Test for Steroids. $5 \mathrm{ml}$ plant extract was added with $2 \mathrm{ml}$ of glacial acetic acid. A drop of ferric chloride solution was added. Inclining the test tube, $1 \mathrm{ml}$ of concentrated sulfuric acid was then added carefully by means of a pipette. At the separations level of the two liquids, a formation of reddish-brown ring at the interface indicates the presence of steroids. Violet ring may appear below brown ring or greenish in acetic acid layer is also a positive indication.

Test for Anthraquinones. $0.5 \mathrm{~g}$ of crude powder was shaken with $10 \mathrm{ml}$ of benzene and was filtered $0.5 \mathrm{ml}$ of $10 \%$ ammonia solution was added to the filtrate and the mixture was shaken well and the presence of the violet color in the layer phase indicated the presence of the anthraquinones.

\section{RESULTS AND DISCUSSION}

Antidesma bunius Linn. (Spreng.) [Family: Phyllanthaceae] [English name: Chineselaurel, Herbert River-cherry, Queensland-cherry, salamander tree, wild cherry, currant tree] [Synonyms:
Antidesma bunius var. bunius, Antidesma bunius var. cordifolium (C.Presl) Müll.Arg., Antidesma bunius var. floribundum (Tul.) Müll.Arg., Antidesma bunius var. pubescens Petra Hoffm., Antidesma bunius var. sylvestre (Lam.) Müll.Arg., Antidesma bunius var. thwaitesianum (Müll.Arg.) Trimen, Antidesma bunius var. wallichii Müll.Arg.], locally named as bignay, is a small, smooth dioecious tree, 4 to 10 $\mathrm{m}$ high ${ }^{21}$. Female trees bear some fruit without the presence of a male tree since many of the flowers are perfect. Leaves are small, dark green, shiny, alternate, pointed at the tip, rounded or pointed at the base, 8 to $20 \mathrm{~cm}$ in length (Fig. 2). In countries like the Philippines and Indonesia, the leaves are consumed raw, stewed with rice or blended with other vegetables. Flowers are small, green, and odorous. Fruit is thin-skinned, spherical to ovoid, dark red when ripe, small, juicy, sour, and well-flavored. It contains a single flat seed.

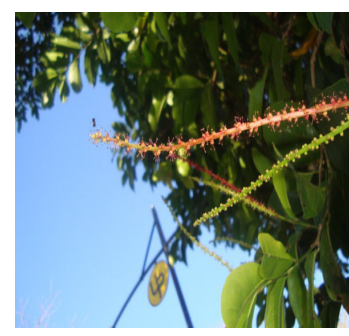

(a)

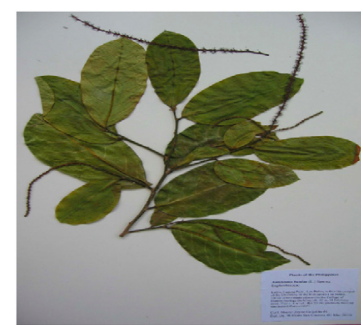

(c)

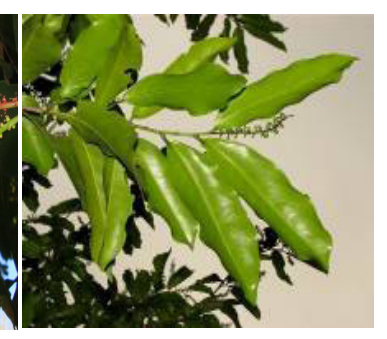

(b)

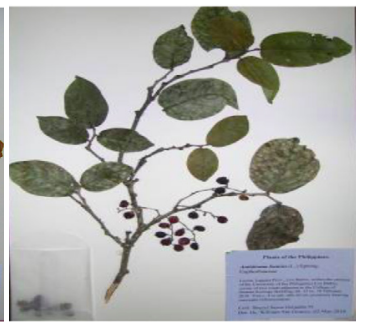

(d)
Fig. 2. Male (A) and female (B) leaves and flowers of the collected $A$. bunius plants. Voucher specimens of the male (C) and female (D) collected plant samples

Phytochemical extraction was done using both $80 \%$ ethanol and aqueous solvents to facilitate extraction of the polar components ${ }^{22,23,24}$. Extraction with $80 \%$ ethanol and drying in vacuo produced a sticky green extract from both the male and female A. bunius leaves. On the other hand, extraction with water and subsequent lyophilization produced fine brown powder from both the male and female A. bunius leaves. Visually, there was no difference between the male and female extracts, but there 
was a visual difference between the ethanolic and aqueous extracts (Figure 3 ).

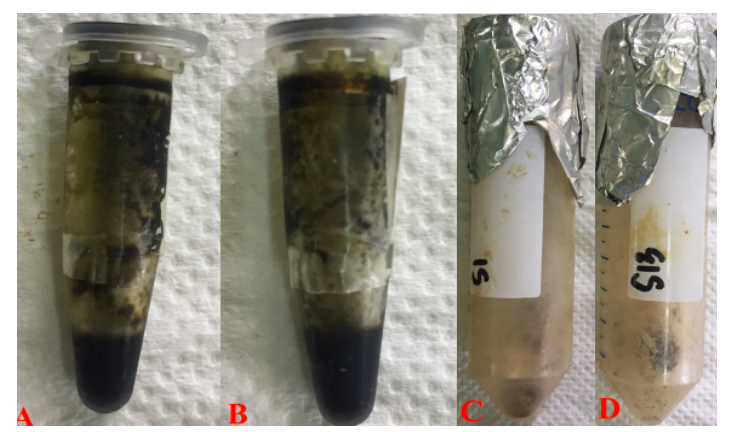

Fig. 3. Male (A) and female (B) A. bunius leaf ethanolic $(80 \%)$ extracts. Male (C) and female (D) A. bunius leaf aqueous extracts

The acute oral toxicity test was performed based on the OECD (Organization for Economic Co-operation and Development) Guideline No.
423: Acute toxic class method as in Annex 2d: Test procedure with a starting dose of $2000 \mathrm{mg} / \mathrm{kg}$ body weight ${ }^{18}$. Based on this acute oral toxicity test, all extracts were found to have an LD50 of $1000 \mathrm{mg} /$ $\mathrm{kg}$. The result agreed with the published Material Safety Data Sheet (MSDS) of Antidesmia bunius (L.) Spreng extracts, where the LD50 found was $1 \mathrm{~g} / \mathrm{kg}$ $(1000 \mathrm{mg} / \mathrm{kg})$ in mouse models ${ }^{25}$. Moreover, body weights of the animals in almost all groups (groups 1-6) were found to not differ significantly on day 14 compared to the basal measurement (paired sample t-test, $p$-value $=0.07247,0.33192,0.87585,0.53634$, 0.66991 , and 0.15185 , respectively). Surprisingly, the mean body weights of the animals in group 7 ( $A$. bunius male ethnolic) decreased significantly after the 14 day period ( $p$-value $=0.01194<0.05$ ) From these data, a dose of $500 \mathrm{mg} / \mathrm{kg}$ was selected for the experimental proper.

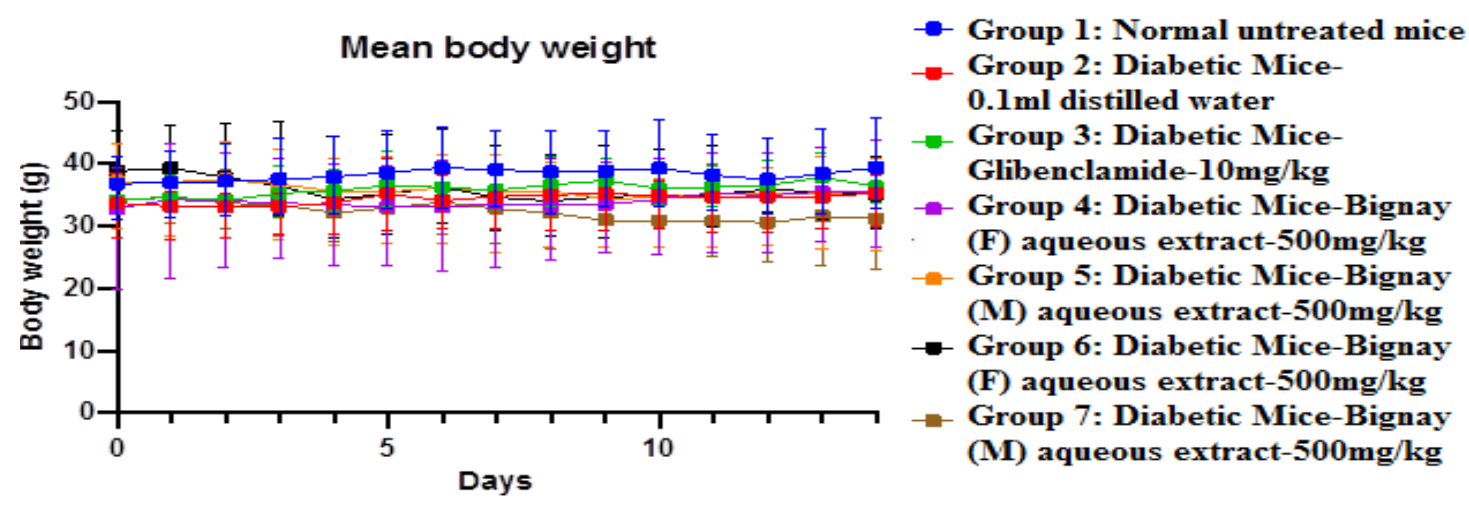

Fig. 4. Mean body weight of non-diabetic control and alloxan induced-diabetic mice treated and non-treated with Bignay extracts $(n=7)$

The hypoglycemic activity of male and female $A$. bunius leaf extracts were evaluated in alloxanized rats. At all time points, all treatments have significantly reduced FBG levels compared to the negative control (One-way ANOVA, p-value $=0.0069,0.0007,<0.0001$, and <0.0001) (Fig. 5). Upon treatment with $A$. bunius female aqueous and $A$. bunius male aqueous extracts produced a significant decrease in FBG levels at day 3 (paired t-test, $p$-value $=0.03622$ ), and day 7 (paired t-test, $p$-value $=0.00573$ ) and day 14 (paired t-test, $p$-value $=0.02116$ ), respectively of the four extracts, aqueous male $A$. bunius extract had the highest FBG-lowering effect with decrease - compared to day 0 - by 18.86 $\pm 14.17 \%, 31.46 \pm 14.62 \%$, and $61.26 \pm 17.89 \%$ after 3,7 , and 14 days of administration. Aqueous female A. bunius extract also had significant FBG-lowering activity, with decrease by $4.03 \pm 17.11 \%, 19.62 \pm$ $27.43 \%$, and $35.75 \pm 11.95 \% 3,7$, and 14 days after Day 0. For the positive control glibenclamide, the FBG levels have only started to decrease after the $14^{\text {th }}$ day since hyperglycemia induction. In the initial clinical trials of glibenclamide by Bhatia et al., (1970), the treatment periods ranged from 1-13 months (mean 6.6 months) ${ }^{26}$. Moreover, there was a pronounced decrease in FBG levels after 1 month of treatment to the patients. Once ingested, glibenclamide binds to the surface receptors of the $\beta$-cell membrane, inhibiting ATP-sensitive potassium channels and causing depolarization of the cell membrane ${ }^{27}$. Depolarization then leads to potassium channel opening, which enables extracellular calcium to enter the cell. Increased intracellular calcium concentration enhances the bounding of 
calcium to the transport protein calmodulin. This leads to microfilament contraction and release of insulin-containing granules. Increased insulin secretion cause consequent reduction of the serum glucose, which improves $\beta$-cell sensitivity to glucose and potentiates insulin secretion. Considering that alloxan, which destroys pancreatic $\beta$-cells, was used to induce hyperglycemia, then we could expect that glibenclamide should work best once the pancreatic $\beta$-cells have regenerated.

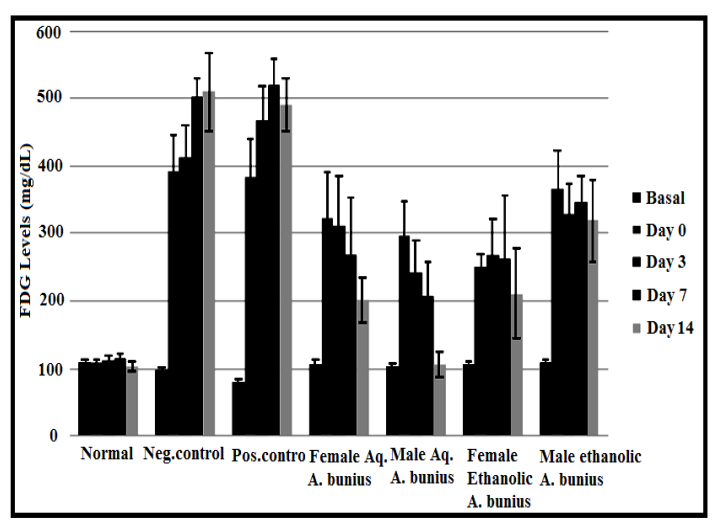

Fig. 5. FBG levels $(\mathrm{mg} / \mathrm{dL})$ of mice before and right after induction of diabetes and 3, 7, and 14 days after administration of treatments

The antidiabetic effect of $A$. bunius has been reported previously. Its fruit ethanolic extract $(500 \mathrm{mg}$ extract/kg body weight) was found to be effective in lowering the FBG levels of alloxanized ICR mice compared to the positive control Metformin ${ }^{28}$. Its partially purified ethanolic fruit extracts were also found to lower FBG levels in alloxanized Balb/C mice ${ }^{29}$. The partially purified ethanolic fruit extract also exhibited $\alpha$-glucosidase inhibitory activity, free radical scavenging activity, iron (III) chelating activity, and ferric ion reducing activity ${ }^{30}$. Additionally, its leaf ethanolic extract was found to inhibit $\alpha$-glucosidase, with an $\mathrm{IC}_{50}$ of $34.77 \pm 1.66 \mu \mathrm{g} / \mathrm{mL} 10$.

The diabetic hyperglycemia induced by alloxan increases plasma levels of urea and creatinine, which are considered as significant markers of renal dysfunction. All groups had BUN levels still within the normal range $(8-33 \mathrm{mg} / \mathrm{dL})$, but only the groups treated with aqueous and ethanolic female $A$. bunius and aqueous male $A$. bunius extracts had normal creatinine levels $(0.2-0.9 \mathrm{mg} /$ $\mathrm{dL}$ ) (Table 2$)^{31}$. Moreover, only the groups treated with glibenclamide and $A$. bunius ethanolic extract had BUN and creatinine levels to be statistically insignificant compared to the negative control ${ }^{31}$. Creatinine levels are used in assessing renal function in mice, particularly glomerular filtration rate; elevated creatinine levels imply decreased renal function ${ }^{32}$. For humans, the markers of renal function in routine analysis include creatinine and urea, as well as uric acid and electrolytes ${ }^{33}$. Urea, a major nitrogenous end product of protein and amino acid degradation, is useful in differential diagnosis of acute renal failure and prerenal conditions ${ }^{34}$. Increased BUN levels have been associated with kidney diseases, blockage of the urinary tract, congestive heart failure, dehydration fever, shock, and bleeding in the digestive tract ${ }^{33}$.

Table 2: BUN (mg/dL) and creatinine $(\mathrm{mg} / \mathrm{dL})$ of the mice after the 14-day period ${ }^{\star \star *}$

\begin{tabular}{|c|c|c|c|c|}
\hline Group & $\underset{(\mathrm{mg} / \mathrm{dL})}{\mathrm{BUN}}$ In & $\begin{array}{c}\text { Interpretatio } \\
(\mathrm{BUN})^{19}\end{array}$ & $\begin{array}{c}\text { on Creatinine } \\
(\mathrm{mg} / \mathrm{dL})\end{array}$ & $\begin{array}{l}\text { Interpretation } \\
\text { (Creatinine) }^{19}\end{array}$ \\
\hline Normal & $10.93 \pm 0.92^{*}$ & ${ }^{*}$ Normal & $0.946 \pm 0.074^{\circ}$ & $\begin{array}{c}{ }^{\circ} \text { Borderline } \\
\text { normal }\end{array}$ \\
\hline Neg. Control & $23.13 \pm 3.52^{*}$ & Normal & $3.3 \pm 0.59$ & $\begin{array}{l}\text { Above } \\
\text { normal }\end{array}$ \\
\hline Pos. Control & $15.47 \pm 0.80^{*}$ & )$^{*}$ Normal & $2.63 \pm 0.189$ & $\begin{array}{l}\text { Above } \\
\text { normal }\end{array}$ \\
\hline $\begin{array}{c}\text { Female Aq. } \\
\text { A. bunius }\end{array}$ & $10.17 \pm 2.204^{*}$ & $4^{*}$ Normal & $0.56 \pm 0.06^{\star *}$ & Normal \\
\hline $\begin{array}{l}\text { Male Aq. } \\
\text { A. bunius }\end{array}$ & $7.62 \pm 0.77^{\circ}$ & $\begin{array}{c}\text { Borderline } \\
\text { normal }\end{array}$ & $0.62 \pm 0.011^{* *}$ & $* \quad$ Normal \\
\hline $\begin{array}{l}\text { Female EtOH } \\
\text { A. bunius }\end{array}$ & $8.03 \pm 1.11^{*}$ & * Normal & $0.55 \pm 0.08^{* *}$ & * Normal \\
\hline $\begin{array}{l}\text { Male EtOH } \\
\text { A. bunius }\end{array}$ & $16.87 \pm 3.53^{*}$ & $3^{\star} \quad$ Normal & $2.38 \pm 0.86$ & $\begin{array}{l}\text { Above } \\
\text { normal }\end{array}$ \\
\hline
\end{tabular}

${ }^{* * \star}$ Data expressed as Mean \pm SD

For the phytochemical analysis, female Antidesma bunius leaves showed positive results for all the constituents analyzed, except for anthraquinones, alkaloids and flavonoids while male Antidesma bunius leaves showed positive results in the tests done for the presence of saponins, steroids, phlobatannins, tannins and polyphenols (Table 3). Although several studies have compared the individual secondary metabolites between other dioecious species, such as in Mauritia flexuosa ${ }^{15}$, Tinospora cordifolia ${ }^{16}$, and Piper betle ${ }^{17}$, the in-depth comparison of $A$. bunius male and female leaves have not been done prior. Here, the results show through preliminary methods that terpenoids were present in detectable quantities in the female $A$. bunius samples compared to the male. Additional analyses, such as through phytochemical quantification or mass spectrometry, could be performed to study this further. 
Table 3: Phytochemical screening of the extracts based on the protocols by Edeoga $(2005)^{20}$. Legend: '+'=detected, '-'=not detected

\begin{tabular}{lcc}
\hline Phytochemical & Female A. bunius & Male A. bunius \\
\hline Flavonoids & - & - \\
Alkaloids & - & - \\
Saponins & + & + \\
Tannins and Polyphenols & + & + \\
Phlobatannins & + & + \\
Terpenoids & + & - \\
Steroids & + & + \\
Anthraquinones & - & - \\
\hline
\end{tabular}

Phenolic compounds are known to be effective antioxidants ${ }^{35}$. Antioxidants have been shown to be beneficial to diabetics by decreasing the risk of complications ${ }^{36}$. In various studies, antidiabetic drugs and antioxidants delayed or prevented the onset of type 2 diabetes mellitus in patients with impaired glucose tolerance ${ }^{37,38,39}$.
Saponins from a variety of sources have been shown to have hypocholesterolemic, anticoagulant, anticarcinogenic, hepatoprotective, hypoglycemic, immunomodulatory, neuroprotective, anti-inflammatory, and antioxidant activity ${ }^{40}$. Several terpenoids, such as camphene, lycopene, kaempferol, and myristicin have been shown to be beneficial in treating diabetes ${ }^{41}$.

\section{ACKNOWLEDGMENT}

The authors would like to acknowledge the contributions of Ofelia Tam, Rikkamae Walde, Diomerl Baldo, Reeva Sumulong, and Kenneth Llena for their help in critical reading the manuscript.

\section{Conflicts of Interest}

The authors declare no conflict of interest.

\section{REFERENCES}

1. World Health Organization. Available from http://www.who.int/diabetes/en/., 2010.

2. International Diabetes Federation. Available from: http://www.idf.org/global-diabetesscorecard/assets/downloads/Scorecard-2907-14.pdf., 2014.

3. Retnakaran R; Cull CA; Thorne Kl; Adler Al; Holman RR. Diabetes., 2006, 55, 1832-1839.

4. Evan A, Mong SA, Connors BA, Aronoff GR, Luft FC. Anat Rec., 2005, 208(1), 33-47.

5. Hui H, Tang G, Go VLW. Chin Med J., 2009, 4(11), 1111-1125.

6. Kambouche N, Merah B, Derdour A, Bellahouel S, Dicko A, Younos C, Soulimani R. Afr J Biotechnol., 2009, 8, 5589-5594.

7. Reyes BAS, Bautista ND, Tanquilut NC, Anunciado RV, Leung AB, Sanchez GC, Magtoto $\mathrm{RL}$, Castronuevo P, Tsukamura H, Maeda KI. Afr J Biotechnol., 2006, 105(1/2), 196-200.

8. Tanquilut NC, Tanquilut MRC, Estacio, MAC, Torres EB, Rosario JC, Reyes BAS. J Med Plants Res., 2009, 3(12), 1066-1071.

9. Quisumbing E. Philippines: Katha Publishing Co., Inc., 1978.

10. Lawag I, Aguinaldo A, Naheed S, Mosihuz zaman M. J Ethnopharmacol., 2012, 144 (2012), 217-219.

11. Samappito S, Butkhup L. Pakistan J Bio Sci., 2008, 11, 1654-1661.

12. Hui WH, Sung ML. Aus J Chem., 1968, 21,
2137-2140.

13. Simpson BS. Planta Med., 2013, 79, 613-615.

14. Seethapathy GS, Ravikumar K, Paulsen BS, de Boer HJ, Wangensteen H. J Ethnopharm., 2018, 221, 56-64.

15. dos Santos Freitas D, Alcantara GB. Phytochem Anal., 2017, 29(3), 316-324.

16. Choudhry N, Singh S, Siddiqui MB, Khatoon S. BioMed Res Int., 2014, Article ID 902138

17. Tripathi S, Singh N, Shakya S, Daangi A, Misra-Bhattacharya S, Dube A, Kumar N. Curr Sci., 2006, 91, 746-749.

18. Organization for Economic Co-operation and Development. Available from: https:// ntp.niehs.nih.gov/iccvam/suppdocs/feddocs/ oecd/oecd_gl423.pdf., 2001.

19. Tafesse TB, Hymete A, Mekonnen Y, Tadesse M. BMC Complement Altern Med., 2017, 17, 243.

20. Edeoga HO, Okwu DE, Mbaebie BO. Afr J Biotechnol., 2005, 4, 685-688.

21. Coronel RE. Promising Fruits of the Philippines Phillipines: UPLB., 1983.

22. Cieniak C, Walshe-Roussel B, Liu R, Muhammad A, Saleem A, Haddad PS, Cuerrier A, Foster BC, Arnason JT. J Pharm Sci., 2015, 18(4), 484-493.

23. Makanjuola AS. Food Sci Nutr., 2017, 5(6), https://doi.org/10.1002/fsn3.509.

24. Tiwari P, Kumar B, Kaur M, Kaur G, Kaur H. Int Pharm Sci., 2011, 1(1), 98-106. 
25. Indian Journal of Experimental Biology. 1990, 28, 619.

26. Bhatia SK, Hadden DR, Montgomery DAD, Weaver JÁ. Brit Med J., 1970, 2(5709), 570-572.

27. Serrano-Martin X, Payares G, Mendoza-León A. Antimicrob Agents Chemother., 2006, 50(12), 4214-4216.

28. Alvarado J, Quiming N, Nicolas M, Verzosa D, Alvarez MR. J Chem Pharm Res., 2015, 7(12), 265-270.

29. Quiming N, Dayanan JN, Nicolas M, Verzosa D, Alvarez MR. J App Pharm Sci., 2017, 7(2), 120-123.

30. Quiming N, Asis JL, Nicolas M, Verzosa D, Alvarez MR. J App Pharm Sci., 2016, 6(5), 97-101.

31. Research Animal Resources, University of Minnesota, n.d. Available from: https://www. ahc.umn.edu/rar/refvalues.html.

32. Dunn S, Qi Z, Bottinger E, Breyer M, Sharma K. Kidney Int., 2004, 65(5), 1959-1967.
33. Gowda S, Desai PB, Kulkarni SS, Hull VV, Math AAK, Vernekar SN. N. Am. J. Med. Sci., 2010, 2(4), 170-173.

34. Mithcell HR, Kline W. Am. J. Kidney Dis., 2006, 47, 174-183.

35. Rice-Evans C, Miller N, Paganga G. Trends Plant Sci., 1997, 2(4), 152-159.

36. Bonnefont-Rousselot D. Treat Endocrinol ., 2004, 3(1), 41-52.

37. Phung OJ, Sood NA, Sill BE, Coleman Cl. Diabetic Med., 2011, 28(8), 948-964.

38. Kawamori R, Tajima N, Iwamoto Y, Kashiwagi A, Shimamoto K, Kaku K. Lancet., 2009, 373(9675), 1607-1614.

39. Montonen J, Knekt P, Järvinen R, Reunanen A. Diabetes Care., 2004, 27(2), 362-366.

40. Rao AV, Gurfinkel DM. Drug Metabol Drug Interact., 2000, 17(1-4), 211-235.

41. Tang GY, Li XJ, Zhang HY. Molecules., 2008. 13, 1189-1194. 